\title{
Seeing through the 'MIST' (minor impact soft tissue injury)?
}

\author{
Eldon Tunks MD FRCPC
}

$I^{n}$ $\mathrm{n}$ this issue, Centeno et al (pages 71-74) discuss the merits of the concept of 'minor impact soft tissue injury' (MIST), or chronic pain after whiplash-associated disorder.

We like to think of ourselves as reasonable clinicians and that clinical beliefs that are long-held and with apparent face validity do not need more proof. Yet, often we find that when venerable opinions are put to the test in clinical trials, some are refuted. With regard to 'whiplash-associated disorder', one might assume that once we have excluded fracture and neural injury, we are left with soft tissue (muscular and ligamentous) sprain/strain as the only remaining mechanism of injury. By analogy to sprains and strains elsewhere in the body, we might reasonably assume that the healing curve for this soft tissue follows a time-limited trajectory of inflammation and healing, that pain might be expected during that healing process (from two weeks to two months at the outside) and, that, by the end of that time, no impairment or disability should remain from the whiplash injury.

Centeno et al examined two main hypotheses inherent in the 'sprain/strain' view of whiplash:

1. It is virtually impossible to sustain a permanent or serious injury in a low-damage car crash; and

2. Whiplash is only muscle and ligamentous sprain and strain, and should always resolve on its own, in no more than a few weeks.

The authors noted that the hypothesis that the severity of the crash should determine the severity of injury has not been supported by crash studies. They point out that studies dealing with simulated crash data and real-world crash data from 'black boxes' installed in vehicles have found that ' $\Delta \mathrm{V}$ ', or the change in velocity during crashes, does not bear a consistent or expected relationship to injuries, and low-damage accidents can be accompanied by occupant injury. The relationship between accident severity and occupant injury is determined by interactions between the overall energy of the accident, the stiffness and elasticity of the vehicles, seat design, head restraint, occupant mass and position, vehicle design with crumple zones, and other factors such as the addition of a tow hitch and whether the occupant is male or female.

The assumption that minor accidents should result in a shortterm strain that should always resolve on its own has remained a contentious issue between frontline clinicians who treat and follow these patients and who know their pain and struggles, and clinicians providing insurance medical examinations who, having seen the patient once, sometimes dogmatically maintain that despite the persistent complaint, the injury is really trivial and that the prognosis is excellent. There are various lines of evidence that call the assumption of trivial soft tissue injury into question. In their extensive narrative review, Barnsley et al (1) compiled evidence that whiplash accidents are associated in some cases with damage to the zygapophyseal joints, intervertebral disk avulsion, tear of the anterior annulus fibrosus and anterior longitudinal ligament, and accelerated onset of degenerative changes in the cervical spine. Other whiplash-associated injuries may include muscle tears, prevertebral hematomas, damage to temporomandibular joints, cerebral injuries and spinal fractures. Chung and Han (2) noted subintimal tears of the vertebral-basilar artery in patients who previously had minor neck injury, including whiplash. Spinal cord injury may occur in a subgroup of whiplashinjured patients. Guez et al (3) found positive assays for neurofilament protein in patients with myelopathy and also in three of 17 whiplash patients.

That pain may arise from damaged zygapophyseal joints is supported through placebo-controlled blocks, and prolonged relief through radiofrequency blocks of joint innervation has been reported (4).

The pain generator for chronic postwhiplash pain may be in the central nervous system and not just in the neck. Sensitization within the nervous system is suggested by the observation that widespread myofascial pain (or fibromyalgia) is encountered in some whiplash patients months and years after the accident (5). This hypothesis is further supported by the finding of widespread alteration in responsiveness to thermal and pressure stimuli, but not touch, at an average of 18 months after whiplash injury (6).

The outcome of neck injury is by no means guaranteed to be favourable. Although the majority improve and resolve during the first month, a significant minority continue to have problems for much longer $(1)$. Berglund et al $(7,8)$ found that compared with noninjured subjects, injured subjects showed an increased RR (relative risk) of neck and shoulder pain, headache, thoracic and low back pain, fatigue, sleep disturbances and ill health seven years after whiplash injury. In a small case series of 50 whiplash patients, Gargan and Bannister (9) found that nine of the 15 patients who improved between three months and one year had relapsed by two years. Because of this prolonged course of pain and/or tendency to relapse, a prospective study of whiplash outcome that uses the 'closure of a claim on return to work' as a model, as employed by the Quebec Task Force (10), is likely to result in too optimistic a prognosis. The Quebec Task Force study (10) has also been criticized on methodological grounds (11). In the Quebec Task Force study, the main outcome variable was time to closure of claim for those 
who did not have recurrent symptoms from the same injury. This outcome variable fails to identify those who have recurrences, and biases the results toward a more favourable outcome. The second outcome variable counted those with recurrence of previously resolved symptoms but only in those who were diagnosed with whiplash as their sole injury. The second variable is likely to fail to identify whiplash patients with more severe injuries, and again biases the study toward more favourable outcomes.

By exclusion, some consultants tend to explain any persistence of postwhiplash pain by attributing it to psychological factors, or to exaggeration or malingering. This has been reviewed by Merskey (12). The hypothesis that 'compensationitis' and 'secondary gain' explains prolonged whiplash-associated symptoms has been tested by examining whiplash and prolonged disability in jurisdictions where there is either no compensation or where compensation has been limited to exclude pain and suffering (13-15).

\section{REFERENCES}

1. Barnsley L, Lord S, Bogduk N. Whiplash injury. Pain 1994;58:283-307.

2. Chung YS, Han DH. Vertebrobasilar dissection: A possible role of whiplash injury in its pathogenesis. Neurol Res 2002;24:129-38.

3. Guez M, Hildingsson C, Rosengren L, Karlsson K, Toolanen G. Nervous tissue damage markers in cerebrospinal fluid after cervical spine injuries and whiplash trauma. J Neurotrauma 2003;20:853-8.

4. Lord SM, Barnsley L, Wallis BJ, McDonald GJ, Bogduk N. Percutaneous radio-frequency neurotomy for chronic cervical zygapophyseal-joint pain. N Engl J Med 1996;335:1721-6.

5. Buskila D, Neumann L. Musculoskeletal injury as a trigger for fibromyalgia/posttraumatic fibromyalgia. Curr Rheumatol Rep 2000;2:104-8.

6. Scott D, Jull G, Sterling M. Widespread sensory hypersensitivity is a feature of chronic whiplash-associated disorder but not chronic idiopathic neck pain. Clin J Pain 2005;21:175-81.

7. Berglund A, Alfredsson L, Cassidy JD, Jensen I, Nygren A. The association between exposure to a rear-end collision and future neck or shoulder pain: A cohort study. J Clin Epidemiol 2000;53:1089-94.

8. Berglund A, Alfredsson L, Jensen I, Cassidy JD, Nygren A. The association between exposure to a rear-end collision and future health complaints. J Clin Epidemiol 2001;54:851-6.
Several authors have published criticisms of the methodology in reports that link prolonged whiplash symptoms to availability of compensation. Merskey (16) concluded that the Schrader report (14) probably lacked sufficient power to find differences between whiplash and nonwhiplash subjects on follow-up. The Cassidy et al (13) study of no-fault insurance effects on whiplash claims in Saskatchewan was based on patients for whom claims were not reopened, and patients were excluded if they were hospitalized for more than two days. These exclusions might have biased the outcomes by eliminating those with a worse prognosis and those who were more severely injured.

There is reasonable doubt about the validity of equating 'whiplash-associated disorder' with 'MIST'. For the sake of our patients and the integrity of our science, we as clinicians, independent medical consultants and clinical investigators must take account of the emerging evidence in this field.

9. Gargan MF, Bannister GC. The rate of recovery following whiplash. Eur Spine J 1994;3:162-4.

10. Spitzer WO, Skovron ML, Salmi LR, et al. Scientific monograph of the Quebec Task Force on Whiplash-Associated Disorders: Redefining "whiplash" and its management. Spine 1995;20(Suppl 8):1S-73S. (Erratum in: 1995;20:2372)

11. Freeman MD, Croft AC, Rossignol AM. "Whiplash associated disorders: Redefining whiplash and its management" by the Quebec Task Force. A critical evaluation. Spine 1998;23:1043-9.

12. Merskey H. Research paradigms in psychosomatic medicine with special emphasis on whiplash-cervical hyperextension flexion injury (CHFI). Pain Res Manage 2003;8:13-8.

13. Cassidy JD, Carroll LJ, Cote P, Lemstra M, Berglund A, Nygren A. Effect of eliminating compensation for pain and suffering on the outcome of insurance claims for whiplash injury. N Eng J Med 2000;342:1179-86.

14. Schrader H, Obelieniene D, Bovim G, et al. Natural evolution of late whiplash syndrome outside the medicolegal context. Lancet 1996;347:1207-11.

15. Obelieniene D, Bovim G, Schrader H, et al. Headache after whiplash: A historical cohort study outside the medicolegal context. Cephalalgia 1998;18:559-64.

16. Merskey H. The whiplash debate. CMAJ 2003;169:753. 


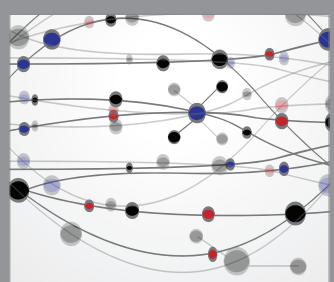

The Scientific World Journal
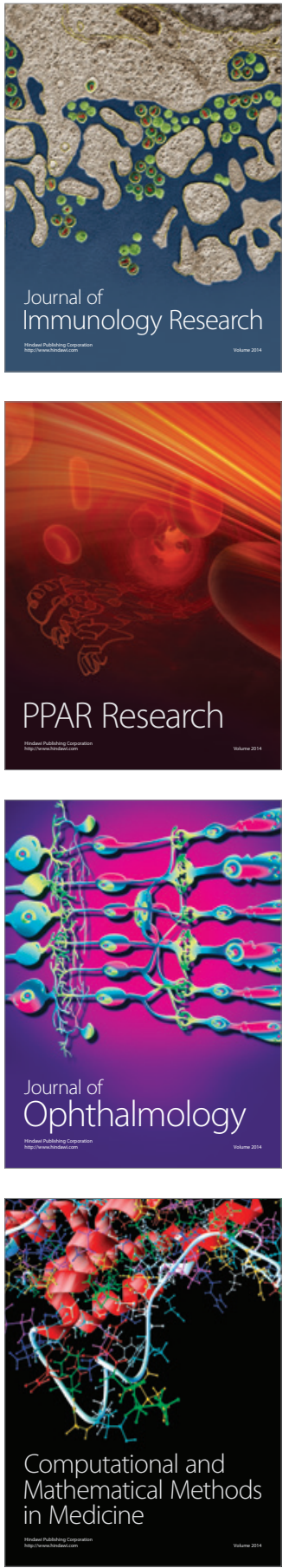

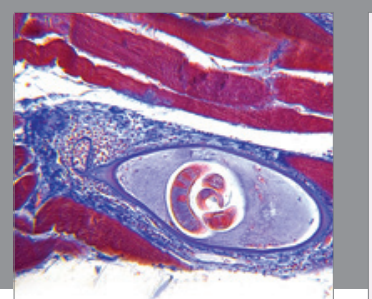

Gastroenterology Research and Practice

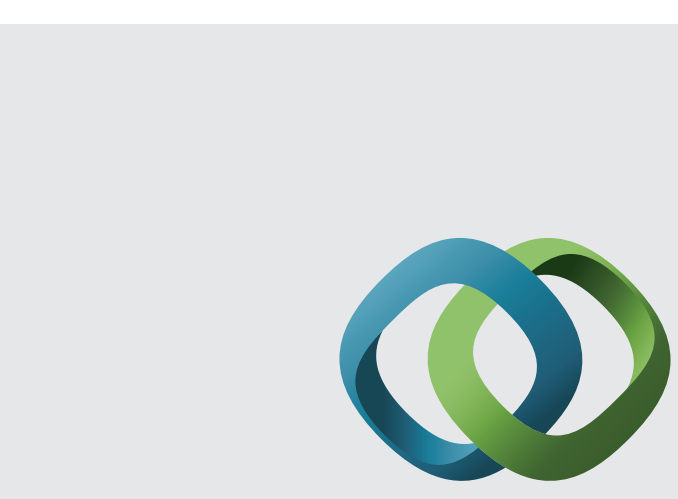

\section{Hindawi}

Submit your manuscripts at

http://www.hindawi.com
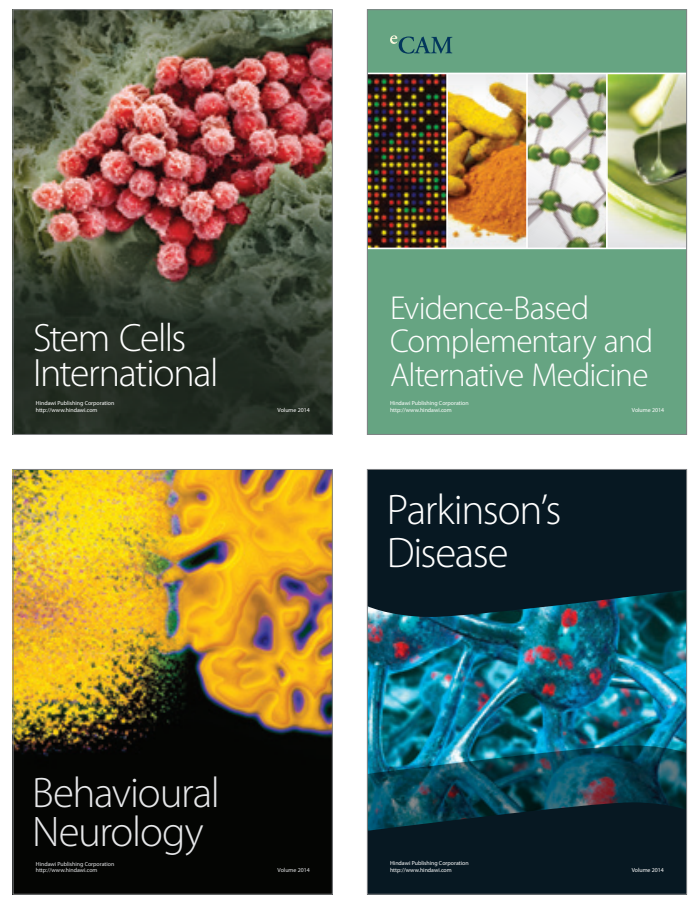
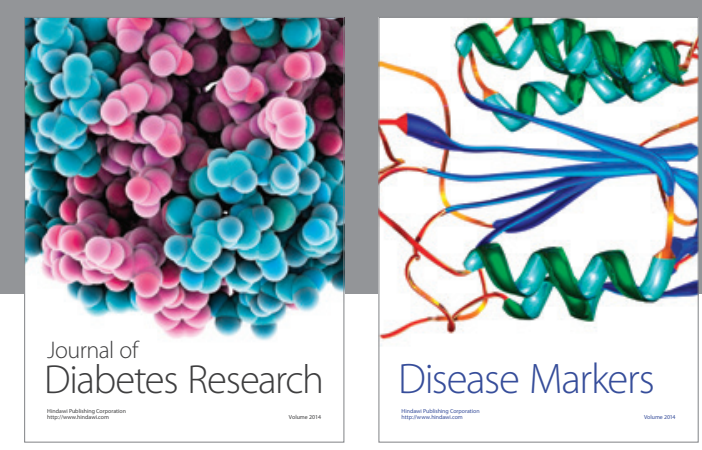

Disease Markers
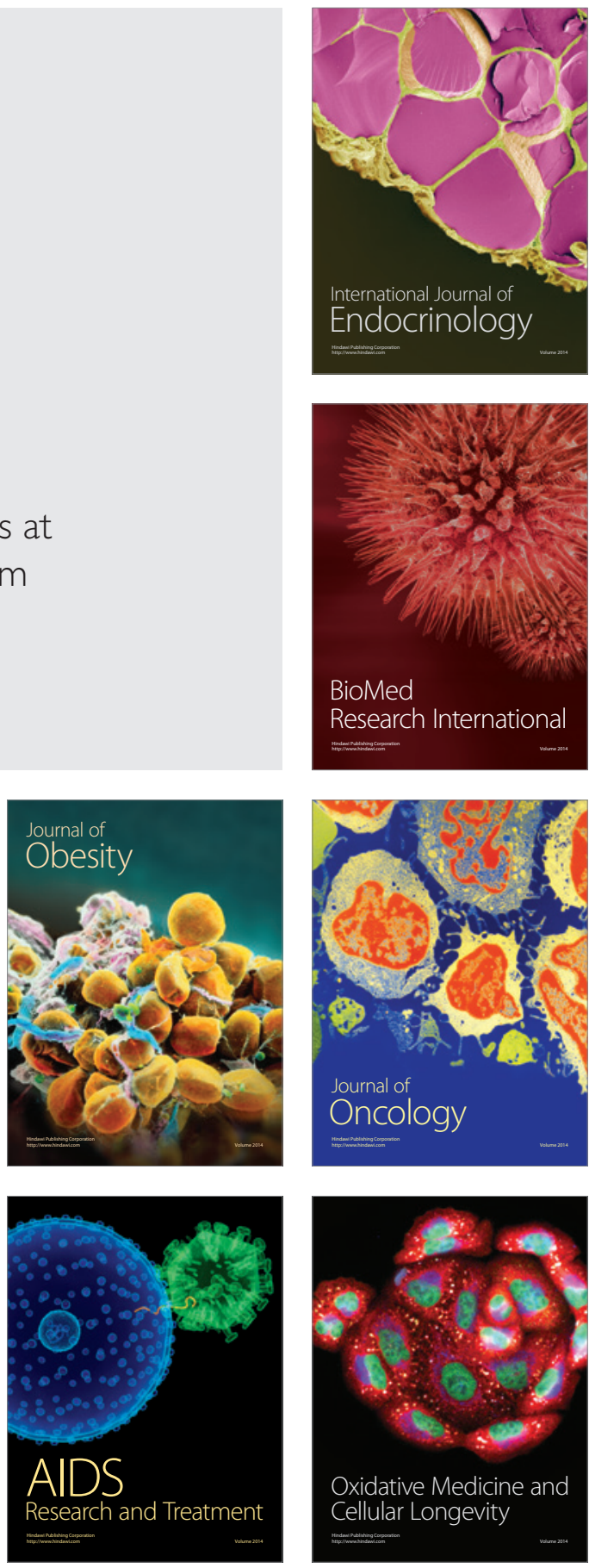